\title{
Obituary
}

\author{
Editor: Henry R. Rollin
}

\section{James Whigham Affleck, formerly Physician Superintendent, Royal Edinburgh Hospital}

The many psychiatrists who worked with Jim Affleck during his long and distinguished career at the Royal Edinburgh Hospital will be sad to hear of his death on 6 March, eight years after his retirement as Physician Superintendent. Born on 8 May 1915, Dr Affleck gave his own personal account of his professional career in the Perspective which he wrote for the Bulletin of September 1986. Entitled 'Clinical Management', the article outlined his early interest in psychiatry as a medical student at Glasgow University, his recognition of the wide prevalence of psychiatric disorders and his awareness of the need to develop appropriate specialist services for different psychiatric illnesses. Following early posts in psychiatry in Scotland, he moved to Leeds in 1948 where his experience as Regional Psychiatrist in the early days of the National Health Service brought home to him the importance of administrative skills in dealing with the needs of psychiatric patients.

Coming to Edinburgh in 1957 as Deputy Physician Superintendent, he found himself sharing in major changes which were affecting the local psychiatric scene - in the development of new clinical services, in massive building programmes and in the expansion of the University Department of Psychiatry - and his personal skills quickly became apparent. Coordinator, diplomat, facilitator (his own favourite term), his contribution to the local service over the following years was quite outstanding and the ready acceptance by his colleagues of his many initiatives was a remarkable tribute to his personal integrity.

Precise in his ways, undemonstrative yet full of underlying vigour, even-tempered, and always ready to give time to everyone who knocked on his door, whether difficult patient or tiresome member of staff, Jim managed to take on many roles including active membership of the Area Health Board, Honorary Senior Lecturer in the University Department of Psychiatry and Chairman of the Scottish Division of the College and Representative on Council from 1973-79. His major clinical interest was in the rehabilitation of long-stay patients and he was a pioneer in the resettlement of patients in the community, involving himself in the creation of strong links with local authority and voluntary groups.

After his retirement in 1980, he was delighted to find himself taking up a new career as Honorary
Senior Lecturer in the University Department of Rehabilitation Studies, where he threw himself into the development of objective measurements of rehabilitation based on his long practical experience.

Those of us who had the opportunity of working closely with him over the years are left with quite special memories, such as his skill in the formal meetings of the Division of Psychiatry and also his views about the future of our specialty expressed in more informal settings - the hospital coffee room on a Saturday morning comes immediately to mind where ideas would be exchanged and where points of interest would be pencilled on to his ever-present notepad, to be used at a later date to enhance the psychiatric service to which he gave such a large part of his life.

He was proud of his three sons, one a teacher and two in the medical profession, and happy in his marriage to Catherine who was always generous and long-suffering in her acceptance that the Royal Edinburgh Hospital had to be seen as part of the family.

There must be many areas in the world where psychiatric practice owes much to the example provided by Jim Affleck and where he is remembered by colleagues with great affection.

He was a Foundation Fellow of the College.

\section{Sir Paul Mallinson Bt, formerly Honorary Consultant Psychiatrist, St George's Hospital, London}

Sir Paul Mallinson, born on 6 May 1909, was educated at Westminster School, Christ Church Oxford, and St Thomas Hospital where he qualified in 1935. Before the war, he gained the MRCP (he was elected to the Fellowship in 1953), the Myers Prize in psychological medicine and a Rockefeller

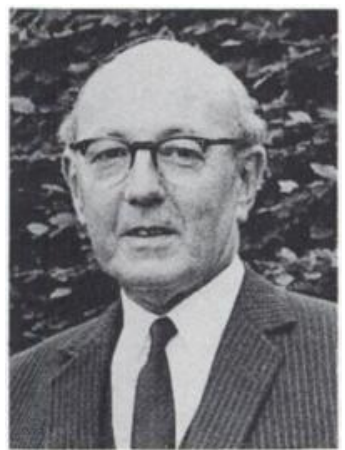
Fellowship. He then served in the RNVR, in a team of talented young psychiatrists, several of whom were to become leading figures in academic psychiatry. After the war he joined Desmond Curran 
(who had commanded the naval team) at St George's Hospital where they, later with Maurice Partridge, built up a psychiatric department based at Knightsbridge and Wimbledon. The department, pre-eminent among the London undergraduate hospitals, was remarkable for the benevolent and caring ambience within which teaching was conducted. Generations of psychiatrists who trained at St George's recall their days there as exceptionally happy, even idyllic.

Paul Mallinson excelled as clinician and teacher. He was elected a Foundation Fellow of the College in 1971 and he examined in psychiatry for the Royal College of Physicians. In addition, he was civilian consultant to the Royal Navy and served as honorary secretary, later vice-president, of the psychiatric section of the Royal Society of Medicine. He was awarded the Order of the Family Brunei (1st Class).

After succeeding to the baronetcy he carried responsibilities in the family timber business, and inevitably these sometimes made claims on his time which competed with those of his medical career. Yet, however hard pressed he was, the personal qualities for which he is so well remembered were always evident: he was infinitely patient, courteous, intuitive and understanding. Although he had a Wimpole Street practice, his hospital patients had the lion's share of his attention, and some enjoyed his personal supportive therapy for years on end. His published work was concentrated in the earlier part of his career, but he later gave his trainees much encouragement in pursuing projects of their own. Former registrars would return to him long after leaving St George's for guidance on their careers, in which he maintained unfailing interest.

He enjoyed cricket and was a member of the MCC. He sailed at Bembridge, where he had a house and entertained a succession of registrars and their families. By his first marriage, he had a son and two daughters of whom one (Angela) is medically qualified. In 1968 he married Dr Margaret Cooper Bowden. His retirement was marred by frequent episodes of ill-health, borne with fortitude and good humour. In his long and painful last illness Paul was sustained by Margaret's devoted care.

DP

\section{Mahenthiran Selvaraj Perinpanayagam, Consultant, Dartford and Gravesham Health Authority}

Dr Perinpanayagam died on 12 October 1988 at the age of 60 . He was born in Sri Lanka and came to the United Kingdom in 1954 a year after graduating MBBS from the University of Ceylon.
He gained experience in a variety of specialities including paediatrics, (he obtained his DCH in 1956) and began his distinguished career in psychiatry in 1960, when he joined Bexley Hospital. He obtained the London University DPM and, as Senior Registrar at Guy's Hospital, came under the tutelage of Dr David Stafford Clark. In 1967 he was appointed Consultant in General Psychiatry to the Dartford and Gravesham. Health Authority, and held this post until his retirement in 1984. He continued his interest in child and adolescent psychiatry and was Consultant Adviser to Kendall House, a home for disturbed adolescents, and also to Rochester Borstal. A popular annual feature at Stone House in Dartford was the Study Day for Sixth Formers from local schools.

Dr Perinpanayagam became Clinical Tutor in 1969 , a role he thoroughly enjoyed. For many years he was the driving force behind the Regional Training Programmes in Psychiatry. He was a founder organiser of the Bi-annual Residential Revision Course for the MRCPsych, held at the University of Surrey, Guildford.

He was closely involved in many College activities, served on the Executive of the Southern Division for many years and between 1974 and 1977 was a member of the Central Accreditation Panel for Approval Visits. He was elected a Fellow of the College in 1975.

Dr Perinpanayagam's approach to patients and colleagues alike was forthright and unequivocal. Meetings sometimes took on an apocalyptic air but it was well known that none other than the deepest concern lay behind the fireworks of his personality. Recipients of his more vigorous manner were carefully chosen by him and they, both patients and colleagues, continued to return to him for the benefit of his opinion. He was quick to size up a situation and had endless patience when patience was needed. His beaming smile seemed to light his way and his charisma gave hope to those in distress. Dr Perinpanayagam took a keen interest in the welfare of overseas graduates and he came to stand as a beacon to many who set out from the Third World.

Dr Perinpanayagam was a keen musician and nurtured a love of music and, whatever the celebratory occasion, he was there playing his 'squeeze box' and delighting his audience.

He retired from the NHS to Guernsey where, despite failing health, he defiantly and courageously carried on working until his return to the mainland, shortly before his death. He will undoubtedly be remembered for his formidable energy, enthusiasm and compassion. He is survived by his wife Pushpam and daughter Malli. 